Article

\title{
An Assessment of Airport Sustainability: Part 3-Water Management at Copenhagen Airport
}

\author{
Glenn Baxter ${ }^{1, *} \mathbb{C}$, Panarat Srisaeng ${ }^{1}\left[\mathbb{D}\right.$ and Graham Wild ${ }^{2}(\mathbb{C}$ \\ 1 School of Tourism and Hospitality Management, Suan Dusit University, \\ Huahin Prachaup Khiri Khan 77110, Thailand \\ 2 School of Engineering, RMIT University, Melbourne, Victoria 3000, Australia \\ * Correspondence: g_glennbax@dusit.ac.th
}

Received: 15 June 2019; Accepted: 10 July 2019; Published: 29 July 2019

check for updates

\begin{abstract}
Sustainable water management is critical for airports as they consume substantial volumes of water to maintain their infrastructure and operations. Airports also generate large volumes of surface and waste waters. The aim of this study was to examine Copenhagen Airport's sustainable water management strategies and systems from 2006 to 2016. The study used a longitudinal qualitative research design. The annual water consumption at Copenhagen Airport has risen from 2006 to 2016 in line with the increased passenger volumes and aircraft movements. Drinking water is sourced from the Taarnby and Dragør municipal water works. Non-potable water is used wherever possible and is sourced from a local remedial drilling. Copenhagen Airport uses two separate sewer systems for handling surface and wastewater. These waters are not discharged to same system due to their different nature. To mitigate environmental risks and impacts on soil, water, and local communities; the quality of drinking, ground, and surface water are regularly monitored. The airport has implemented various water saving initiatives, such as, an aquifer thermal energy system, to reduce water consumption. The strategies, systems, and the water-saving initiatives have successfully underpinned Copenhagen Airport's sustainable water management.
\end{abstract}

Keywords: Copenhagen Airport; storm water; sustainable water management; waste water; water pollution; water quality monitoring

\section{Introduction}

Sustainable water management is a critical issue for airports [1]. This is because airports consume substantial amounts of water to maintain both their infrastructure and operations [2-4]. Large volumes of wastewater are also generated at airports. These wastewaters could have a negative impact on both soil and groundwater since they contain a relatively high concentration of contaminants [5]. Considering these challenges, airports all around the world are now increasingly implementing sustainable water management as a key element of their environmental plans and strategies.

The goal of this work is to undertake a longitudinal case study of sustainable airport water management. A longitudinal study is essential as it enables not only the management strategies to be identified, it allows for an assessment of their effectiveness. As such, the primary objective of this research is to analyze the sustainable water management strategies implemented at Copenhagen Airport and to specifically examine the methods, water quality monitoring, and systems that Copenhagen Airport utilizes to reduce the environmental impact of water consumed and generated at the airport. Secondary objectives of the study are to investigate the surface and waste waters generated at Copenhagen Airport, and to examine the airport's management of storm water runoff, which may contain hazardous contaminants at the airport. The study period in the case study is from 2006 to 2016. To address the study's objectives, the following research questions were examined: Copenhagen 
Airport is Scandinavia's largest airport [6], and as well as being among the European leading airports with respect to technology, the airport is also extremely ecologically conscious [7]. A further reason for selecting Copenhagen Airport as the case company was the ready availability of the airport's annual environmental data—which as previously noted—covered the period from 2006 to 2016.

1. What is the annual water consumption at Copenhagen Airport and has this changed over the period 2006 to 2016 ?

2. What are the principal sources of water used at Copenhagen Airport?

3. How does Copenhagen Airport manage its surface and waste waters?

4. What measures are used to monitor water quality at Copenhagen Airport?

5. What initiatives have been implemented by Copenhagen Airport to mitigate water consumption during the period 2006 to 2016 ?

The research hypotheses posed in response to these research questions are:

1. The annual total water consumption is expected to grow with total traffic at the airport, while efficiency measures should have resulted in a reduction per unit traffic.

2. Ground water is expected to be the principle source of water.

3. Surface water is expected to be captured and treated before being utilized in "grey-water" applications, or discharged into the nearby sea.

4. Based on typical water quality metrics, it is expected that measures are taken for heavy metals and nitrates etc.

5. The standard: reduce, reuse, and recycle strategies of many sustainability initiatives are expected to be utilized.

The remainder of the paper is organized as follows: Section 2 presents a review of the literature on the sustainable water management at airports. The research methodology used to underpin the study is described in Section 3. In Section 4, the results of case study of Copenhagen Airport sustainable water management are presented. Section 5 presents the findings of the study.

\section{Literature Review}

\subsection{Water Usage by the Key Airport Stakeholders}

Water consumed by airports can be broadly divided into the water consumed by the landside activities undertaken at the airport as well as the water consumed by the key stakeholders involved in the provision of services in the airport's airside area. Landside means those parts of an airport as well as the adjacent terrain and buildings or portions thereof that are not in the airside precinct. The airside means the movement area at an airport, adjacent terrain, and buildings/infrastructure (or portions), the access to which is restricted [8]. Airport operators, ground service providers, and passengers and staff require water for drinking, catering, retail, cleaning, flushing toilets, system maintenance, as well as for airport grounds maintenance and landscaping. "The operational capacity of an airport and the level of service quality that is delivered to its customers and service partners can be severely constrained if the airport is unable to guarantee and deliver a secure, adequate, and low-cost supply of water to satisfy peak demand" [9]. Thus, to maintain airport infrastructure, there are very significant quantities of water required.

Table 1 shows the various stakeholders involved in the facilitation and handling of passengers, and where applicable, air cargo, handled on the landside of an airport. As Table 1 shows water is consumed on the landside of an airport for a variety of purposes. These include drinking water for passengers, meeters and greeters, airport staff, washing of vehicles, the flushing of toilets, personal hygiene (for example, washing of hands and in showers provided for passengers and airport-related staff), as well as for cooking and beverages provided by concessionaires operating at the airport and by flight catering firms. 
Table 2 shows the key stakeholders that are typically involved in the facilitation and handling of aircraft (passenger, freighter, and general aviation aircraft), passenger and air cargo movements, aircraft maintenance, and air traffic control (ATC) on the airside of an airport. Airports also often have concessionaires located in the airside section of the terminal, for example, shops and restaurants $[10,11]$. As Table 2 shows water is also consumed on the airside of an airport for a diverse range of purposes. These include drinking water for airport staff working on the airside, washing of aircraft and ground service vehicles, the flushing of toilets, personal hygiene (for example, washing of hands and in showers provided for airport-related staff), as well as cooking and beverages provided by concessionaires operating restaurants and coffee shops in the airside terminal precinct and by flight catering firms operating on the airside at the airport.

Table 1. Key Airport Landside Stakeholders and their Typical Water Usage Requirements.

\begin{tabular}{|c|c|}
\hline Stakeholder & Water Usage \\
\hline Airport Authority & $\begin{array}{l}\text { Passenger, staff, and public sanitation and hygiene in the airport terminals, drinking water, } \\
\text { fire control, landscaping, water towers, air-conditioning, in addition to washing vehicles } \\
\text { and infrastructure. }\end{array}$ \\
\hline Tenants and Concessionaires & Personnel/customer sanitation and hygiene, drinking water. \\
\hline Airlines & Personnel/customer sanitation and hygiene, drinking water, washing vehicles. \\
\hline Car Parks & Personnel/customer sanitation and hygiene, drinking water, washing vehicles, landscaping. \\
\hline Cargo Terminal Operators 1 & $\begin{array}{l}\text { Personnel/customer sanitation and hygiene, drinking water, washing vehicles and } \\
\text { facilities, landscaping. }\end{array}$ \\
\hline Eateries & $\begin{array}{l}\text { Personnel and food sanitation and hygiene, drinking water, food preparation and beverage } \\
\text { consumption, and washing plates, cups, and utensils. }\end{array}$ \\
\hline Freight Forwarders & $\begin{array}{l}\text { Personnel/customer sanitation and hygiene, drinking water, washing vehicles and } \\
\text { facilities, landscaping. }\end{array}$ \\
\hline Government Agencies & Personnel/customer sanitation and hygiene, drinking water, washing vehicles. \\
\hline Ground Handling Agents & Personnel/customer sanitation and hygiene, drinking water, washing vehicles. \\
\hline Ground Transportation & Personnel/customer sanitation and hygiene, drinking water, washing vehicles \\
\hline Hotels/Motels & $\begin{array}{l}\text { Landscaping, vehicle cleaning, recreational amenities, customer/staff sanitation and } \\
\text { hygiene, food and beverage production. }\end{array}$ \\
\hline Railway Station & Personnel/customer sanitation and hygiene, drinking water. \\
\hline Rental Car Firms & Vehicle cleaning, personnel/customer sanitation and hygiene, drinking water, landscaping. \\
\hline
\end{tabular}

\subsection{Sustainable Water Usage at Airports}

The volume of water used by airports has been estimated to be equivalent to the volume of water that is consumed by mid-size cities [13,14]. London Heathrow Airport, for example, handled around 79 million passengers in 2017 and in facilitating its air traffic demand, the airport uses approximately the same amount of water as the city of Canterbury, United Kingdom, at 2.6 million litres [15]. The implementation of practices and procedures that are aimed at reducing water consumption are therefore both important and necessary [14]. Hence, considering the increasing pressure to reduce water consumption and conserve available water resources, airports must manage their activities and operations to reduce water consumption. They also need to protect surface and ground water resources [3]. To achieve their sustainability objectives, many airports have implemented a range of water-related initiatives including [16]:

1. Reduction in water consumption [17];

2. Re-using water, following treatment (wastewater and sewage treatment plants) in toilet facilities or for irrigation purposes [18];

3. Using rainwater for flushing of toilets [19];

4. Protecting groundwater from pollution [20];

5. Monitoring of water consumption [21]; and

6. Monitoring the quality of the surface and ground water [22]. 
A recent study of an airport in Turkey over the course of a year suggested the use of artificial grass [23]. However, the implications of this would need further investigation, especially the impact to drainage, and on wildlife. To utilize ground water, understanding the pollutants that result from airport operations is essential [24]. Similarly, understanding pollutants present in surface water is essential to know how they can be treated and reused [25]. There is also the possibility of utilizing seawater, given that many airports are positioned in coastal locations [26].

Table 2. Key Airport Airside Stakeholders and their Typical Water Usage Requirements.

\begin{tabular}{|c|c|}
\hline Stakeholder & Water Usage \\
\hline Airport Authority & $\begin{array}{l}\text { Passenger/public sanitation and hygiene in the airport terminals, drinking water, fire } \\
\text { control, landscaping, water towers, air-conditioning, washing vehicles and infrastructure. }\end{array}$ \\
\hline Airport Fuel Farm and Suppliers & Personnel sanitation and hygiene, drinking water, washing vehicles (where applicable) \\
\hline Tenants and Concessionaires & Personnel/customer sanitation and hygiene, drinking water \\
\hline Air Traffic Control & Personnel sanitation and hygiene, drinking water, washing vehicles (where applicable) \\
\hline Maintenance Organisations & $\begin{array}{l}\text { Personnel/customer sanitation and hygiene, drinking water, washing vehicles and facilities, } \\
\text { landscaping }\end{array}$ \\
\hline Airlines & Personnel/customer sanitation and hygiene, drinking water, washing vehicles and aircraft \\
\hline Cargo Terminal Operators & $\begin{array}{l}\text { Personnel/customer sanitation and hygiene, drinking water, washing vehicles and } \\
\text { facilities, landscaping }\end{array}$ \\
\hline Eating and Dining Outlets & $\begin{array}{l}\text { Personnel and food sanitation and hygiene, drinking water, food preparation and beverage } \\
\text { consumption, washing plates, cups and utensils }\end{array}$ \\
\hline Fixed Base Operator (FBO) & Personnel/customer sanitation and hygiene, drinking water, washing vehicles and facilities \\
\hline Flight Catering Centres & $\begin{array}{l}\text { Personnel and food sanitation and hygiene, drinking water, food preparation and beverage } \\
\text { consumption, washing, vehicle cleaning }\end{array}$ \\
\hline General Aviation/Business Jet Centre & $\begin{array}{l}\text { Personnel/customer sanitation and hygiene, drinking water, washing vehicles, aircraft } \\
\text { and facilities }\end{array}$ \\
\hline Government Agencies & Personnel/customer sanitation and hygiene, drinking water, washing vehicles \\
\hline GSE ${ }^{1}$ Maintenance Firms & $\begin{array}{l}\text { Personnel/customer sanitation and hygiene, drinking water, washing vehicles, GSE } \\
\text { equipment and facilities }\end{array}$ \\
\hline Ground Handling Agents & Personnel/customer sanitation and hygiene, drinking water, washing vehicles. \\
\hline
\end{tabular}

Historically, airports have been designed to make use of ground water or water supplied from municipal authorities that satisfy appropriate quality standards. Where this water has only been used for non-industrial purposes (for example, washing, cleaning, and laundry), wastewater can be collected by the airport, treated, and subsequently reused for activities including toilet flushing, washing, and in some instances, the irrigation of plants. Such practices may require the airport to introduce a dual drainage system as well as water-purification facilities [7].

\subsection{Airport Water Quality}

Three forms of water contamination occur at airports: (1) chronic contamination, (2) seasonal contamination associated with de-icing of aircraft and runway procedures during winter operations, and (3) accidental pollution [28]. In an airport's operational area, run-off waters represent a significant environmental threat and could have a negative impact on both soil and groundwater since they contain a relatively high concentration of contaminants [5]. This is because the water quality around airports can be adversely impacted by the runoff of aircraft and airport de-icing operations, together with other sources such as fuel leaks, spills, and solid and liquid waste treatment and disposal [29]. There are other operational activities performed at an airport which can also influence water quality through contaminants being present in the storm water runoff. These include major aircraft overhauls that utilize toxic chemicals to remove paint and the cleaning and re-chroming of engine parts in addition to other light-industrial type activities [30]. The production of in-flight meals, restaurants, and staff canteens also contribute grease and detergents to the waste water generated at an airport [31].

The treatment of such wastes must satisfy health and safety requirements regarding the contents of heavy metals, chlorinated hydrocarbons, and sedimentation substances. Therefore, such pollutants must be properly treated prior to being discharged into the airport's sewage system $[32,33]$. Thus, runoff 
water management is a critical environmental issue for airports and is a key factor in their sustainable and environmental water management.

Other sources of water pollution from an airport include sewage from airport facilities, industrial wastes such as fuel spills, and elevated temperature water degradation from the various power plants located at the airport [34]. Also, construction of an airport and especially the construction of the runway(s) can disturb the ground water system not only in the airport precinct but also in the wider surroundings of the airport [35]. Pollutants that could affect storm water quality at airport construction sites include sediment, oil, grease, and chemicals [36] as well as the discharge of fire-fighting foam in the event of aircraft emergencies [37].

An airport can be a significant contributor to water pollution if suitable facilities to treat airport wastewater are not provided. Drainage from an airport's movement areas require special treatment to remove the oil-products or de-icing chemicals used during the winter period. Sewage water from an airport is cleansed at normal water treatment plants. In addition, rain water off the paved areas, especially from the apron, can be collected and cleaned, separating oils and other contaminates. This can occur either in a dedicated treatment plant located at the airport or alternatively, the collector can be directly linked to the local municipal treatment plant [32] (p. 536).

Furthermore, especially dangerous areas of the airport, for instance, fuel storage, aircraft hangars, and maintenance facilities, need to be equipped with traps for oil products. These facilities need to be inspected regularly. Also, it is important for airports to pay attention to possible water or soil contamination arising from fire-fighting training. Such training activities should only be permitted within a specially designated area at the airport [32].

Most countries have set water quality standards. However, the water quality standards set by airports are normally much more stringent [32]. Around the world, the organic water pollution indicators that are commonly used to measure water pollution are chemical oxygen demand (COD), total nitrogen (T-N), and total phosphorous (T-P) [38]. The chemical oxygen demand (COD) test measures the total amount of oxygen that is required to completely oxidize organic matter to carbon dioxide $\left(\mathrm{CO}_{2}\right)$ and water. Hence, the $\mathrm{COD}$ test provides an indication of its potential maximum oxygen demand $[39,40]$.

Since water sources are often connected to each other, any adverse impacts on the local deterioration of water quality arising from airport operations can have an impact in regions that are located quite a distance from the airport itself [29].

Table 3 presents a summary of the key airport stakeholders' activities which result in wastewaters that require processing prior to being discharged into rivers, local streams, watercourses, or another body of water.

\section{The Case: Copenhagen Airport}

Copenhagen Airport (Figure 1) is in Kastrup, around $11 \mathrm{~km}$ southwest of downtown Copenhagen. The airport is Scandinavia's major airport acting as the transfer point for air traffic travelling between other parts of the world and the many national and regional airports located in Scandinavia as well as the area south of the Baltic Sea. The airport also functions as the hub for SAS Scandinavian Airlines and is therefore one of the Star Alliance hubs [41]. Star Alliance is a network of 28 international airlines that provide services to a total of 1317 airports in 193 countries [42]. Copenhagen Airports A/S (CPH) is the listed company that operates both Copenhagen and Roskilde Airports. There are more than 700 companies located at Copenhagen Airport. These companies have a total work force of around 23,000 employees [43]. Around eighty airlines operate 726 arrival and departures flight per day from the airport. Direct flights are operated to 165 destinations, including 36 long-haul destinations. 
Table 3. Airport stakeholders, Activities and the Types of Wastewater Contaminants Requiring Processing.

\begin{tabular}{|c|c|c|}
\hline Stakeholder & Activity & Types of Wastewater Contaminants \\
\hline & Washing of aircraft and vehicles & Detergents \\
\hline \multirow{2}{*}{ Airline } & De-icing of aircraft & De-icing agents (glycol) \\
\hline & Re-fuelling aircraft and vehicles & Fuels \\
\hline \multirow[t]{2}{*}{ Flight catering } & Food Preparation and cleaning & Detergents and greases \\
\hline & & Chemicals to remove paint, oil and grease \\
\hline Maintenance provider & Aircraft overhaul & $\begin{array}{l}\text { Cleaning, re-chroming, and painting of } \\
\text { aircraft parts }\end{array}$ \\
\hline \multirow[t]{2}{*}{ Fire-fighting } & Fire-fighting & Foam and fire suppression retardants \\
\hline & Washing of aircraft and vehicles & Detergents \\
\hline \multirow{2}{*}{ Ground handling agents } & De-icing of aircraft & De-icing agents (glycol) \\
\hline & Re-fuelling vehicles & Fuels \\
\hline Construction firms & Airport-related construction projects & Sediment, oil, grease, chemicals \\
\hline
\end{tabular}

Copenhagen Airport has a unique geographical location, being located right between Denmark and Sweden. Around 4.1 million live within a $2.5 \mathrm{~h}$ travelling time from Copenhagen Airport [44].

The airport area, which occupies an area of around 11.8 square kilometres, has four discrete geographical sections: Located in the North Area, are the airport's three passenger terminals, a railway station, a car park, a police station, and other administrative functions. The Gate Gourmet catering facilities, the SAS Cargo Center, and SAS's technical area (which includes four large aircraft maintenance hangars) are also located in the North Area. Cargo terminals for DHL Express and SAS, the Veterinary and Customs Centre, air freight forwarding firms, and the LSG Sky Chefs catering facilities are in the airport's East Area. The technical bases for My Travel, Sterling, Danish Air Transport, and North Star are based in the airport's South Area precinct. The West Area of the airport contains Naviair (air traffic management) as well as Copenhagen Airport's technical maintenance facilities. Copenhagen Airport's runway system comprises a main system (direction 22/04) with two parallel runways for aircraft take-offs and landings (3500 and $3300 \mathrm{~m}$ long) as well as a $2800-\mathrm{m}$ cross-runway (direction 12/30). The airport has a total of 108 stands: 9 domestic stands, 43 international stands with passenger loading bridges, 54 remote stands, and 2 helicopter stands [41].

Figure 2 shows the total annual passenger traffic (domestic and international) and aircraft operations at Copenhagen Airport from 2006 to 2016. In 2009, the total annual passenger volumes declined by around 8.4 per cent. However, during 2009, the airport recovered the traffic lost following the Sterling Airlines bankruptcy in 2008. This growth came from services operated by Norwegian Air Shuttle, Transavia, easyJet, and Cimber Sterling (Figure 2) [45]. In 2014, Copenhagen Airport handled 25,627,093 passengers (Figure 2a), which was the first time in the airport's 90-year history that the total annual enplaned passengers surpassed 25 million passengers travelling through the airport [46]. More than 29 million passengers passed through Copenhagen Airport in 2016. This represented a 9.1 per cent increase on 2015 passenger volumes (Figure 2a). The growth recorded in 2016 was driven by an additional 2.3 million international travelers using the airport [47].

As can be observed in Figure $2 \mathrm{~b}$, the total annual aircraft movements declined substantially in 2009 due to the downturn in air traffic demand following the global financial crisis (GFC). 2012 was a difficult year for the international aviation industry. Cimber Sterling was one of the five European airlines that went bankrupt, and the loss of Copenhagen Airport's third-largest customer made its mark, especially on Danish domestic traffic and aircraft movements (Figure 2b) [48]. 


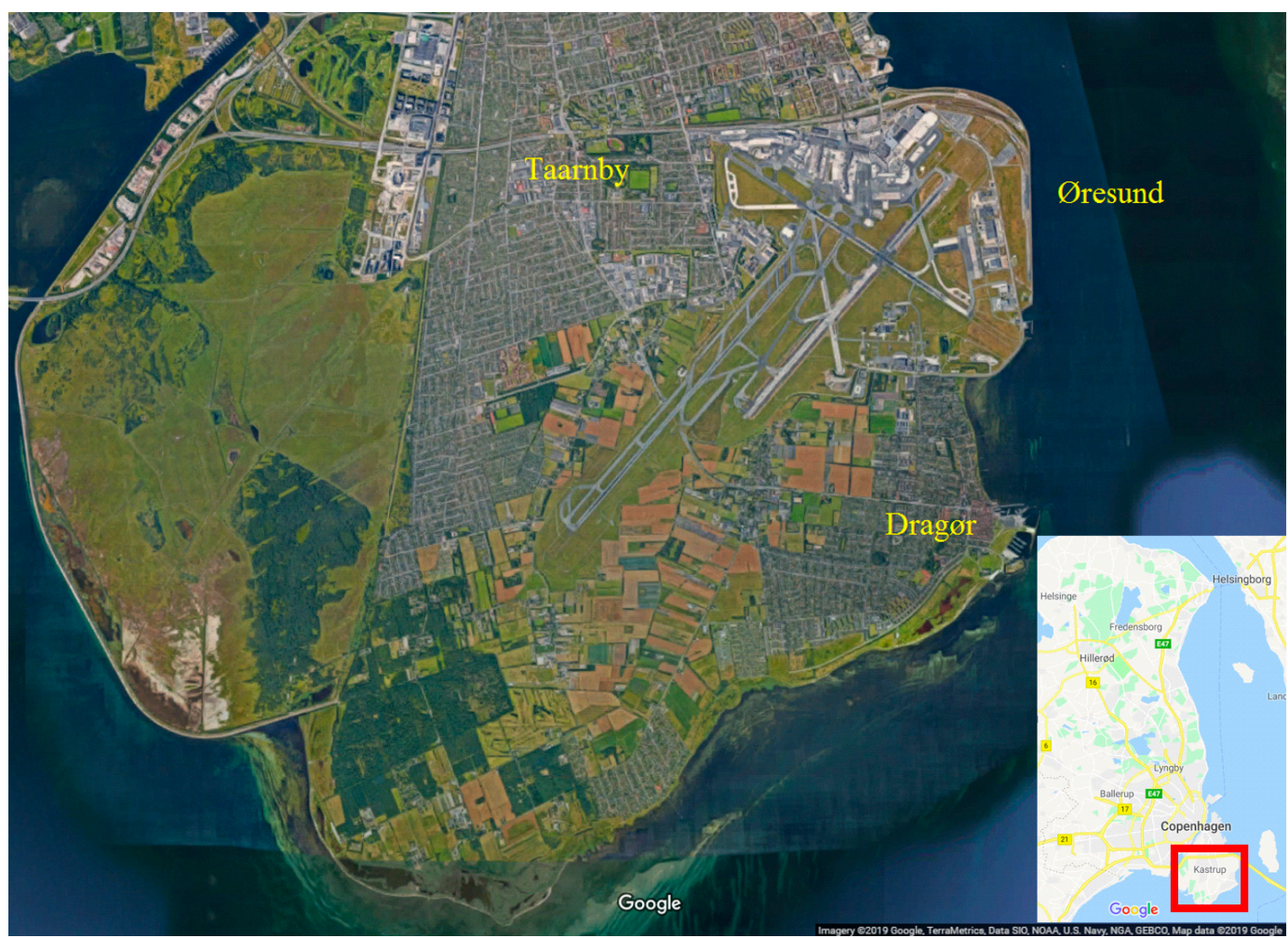

Figure 1. Geography of Copenhagen Airport (CPH), the location of the neighboring areas where water treatment occurs, and the Øresund (sound). Inset: Greater Copenhagen. Source: Imagery (C) 2019 Google, Data SIO, NOAA, US Navy NGA, GEBCO, Map data Google Maps (C) 2019.

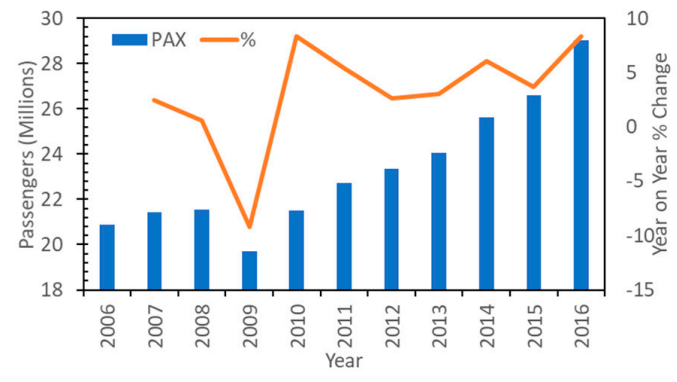

(a)

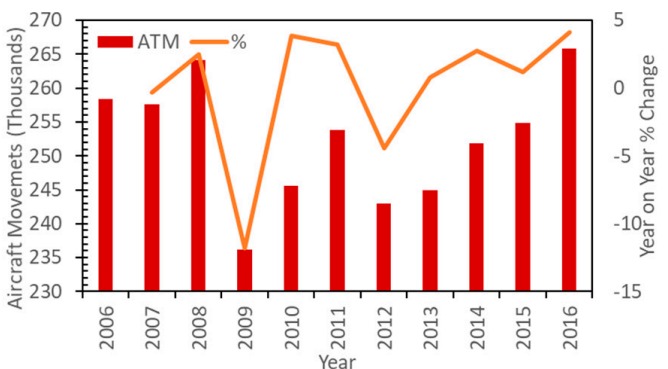

(b)

Figure 2. (a): Total Domestic and International Passengers (PAX) and Year-on-Year Growth Rate (\%) and (b): Total Domestic and International Aircraft Movements (ATM) and Year-on-Year Growth Rate (\%). Source: data derived from [48-52].

\section{Method}

A mixed methods research strategy that included a qualitative longitudinal research approach was used in the study [53-55]. The data for the study was obtained from a range of documents, company materials available on the internet and records as sources of case evidence. Documents included Copenhagen Airports A/S annual environmental reports, Copenhagen Airports A/S group annual reports, press releases, and the airport's websites. The study therefore used secondary data. The three principles of data collection as suggested by Yin [56] were followed: the use of multiple sources of case evidence, creation of a database on the subject and the establishment of a chain of evidence.

The empirical data collected for the qualitative case study was examined using document analysis. Document analysis is often used in case studies and focuses on the information and data from formal documents and company records $[57,58]$. The documents collected for the study were examined 
according to four criteria: authenticity, credibility, representativeness and meaning $[59,60]$. Prior to conducting the formal analysis of the documents gathered in the study, the context in which the documents were created was determined and the authenticity of the documents was assessed [61]. Authenticity involves an assessment of the collected documents for their soundness and authorship. Scott and Marshall [60] (p. 188) note that soundness refers to whether the document is complete and whether it is an original and sound copy. Authorship relates to such issues as collective or institutional authorship. In this study, the source of the case study documents was Copenhagen Airport. The documents were available in the public domain. The credibility criterion concerns the accuracy and sincerity of a document [60]. In the current study, the evidence for the case study was corroborated using various kinds of documents. To alleviate potential bias, documents sourced from various sources were analyzed [61]. The representativeness criterion involved an assessment of the availability and survival of the documents gathered [60,61]. No major difficulties in obtaining documents was experienced in the current study as all the relevant documents were available in the public domain (from Copenhagen Airports A/S website). The fourth criterion, meaning, is a most important matter and occurs at two levels. The first is the literal understanding of a document, by which is meant its physical readability, the language used and whether it can be read, as well as the date of the document [60]. When conducting document analysis in a study, it is important to interpret the understanding and the context within which the document was produced. This enables the researcher to interpret the meaning of the document. The evidence found in the documents collected for the study was clear and comprehensible [62].

Following the recommendations of O'Leary [63], the document analysis process in the present study was undertaken in six discrete phases as follows:

- Phase 1: This phase involved planning the types and required documentation and their availability;

- Phase 2: The data collection involved gathering the documents and developing and implementing a scheme for the document management;

- Phase 3: Documents were reviewed to assess their authenticity, credibility and to identify any potential bias;

- Phase 4: The content of the collected documents was interrogated, and the key themes, data, and issues were identified.

- Phase 5: This phase involved the reflection and refinement to identify and difficulties associated with the documents, reviewing sources, as well as exploring the document's content; and

- Phase 6: The analysis of the data was completed in this final phase of the study [63] (p. 179).

This process is illustrated in Figure 3.

The key words used in the database searches included "Copenhagen Airport regulatory framework", "Copenhagen Airport annual water consumption", "sources of water at Copenhagen Airport", "surface waters at Copenhagen Airport", "wastewater at Copenhagen Airport", "water quality monitoring at Copenhagen Airport", "water contaminants at Copenhagen Airport and "sustainable water saving initiatives at Copenhagen Airport".

Following the recommendations of Yin [56], all the collected documents were downloaded and stored in a case study database. This included the official reports from the airport authority, and any media and trade publications etc., from the online databases. The documents collected for the study were all in English. Each document was carefully read, and key themes were coded and recorded. This study also followed the guidance of van Schoor [62] (p. 94), who has noted that in order to avoid bias, documents from different sources should also be carefully analyzed in the study. In addition, triangulation was used to add discipline to the study. This was achieved by collecting documents from multiple sources. This approach helped verify the themes that were detected in the documents gathered in the study [64]. 


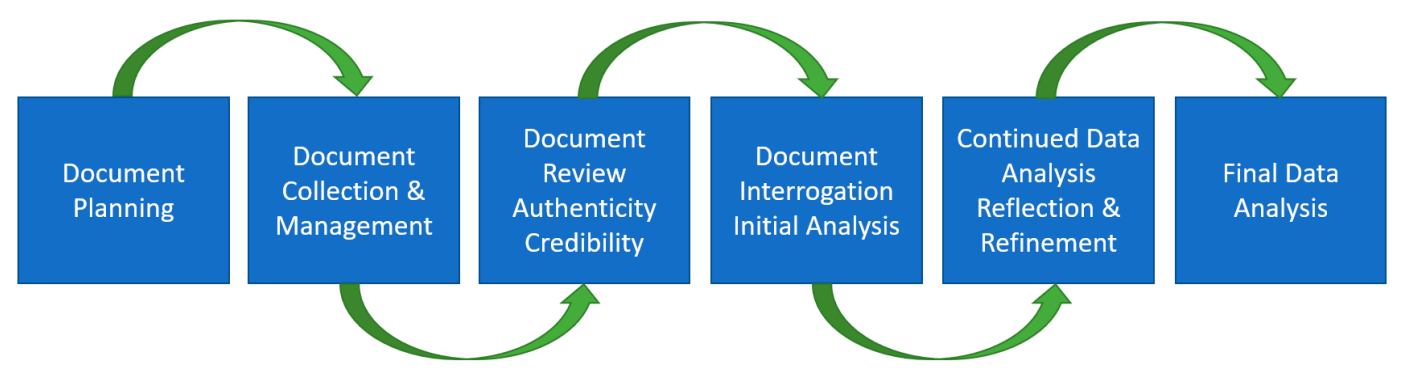

Figure 3. The flow of the research process applied in this study.

\section{Results}

\subsection{Copenhagen Airport Environmental Policy and Regulatory Framework}

The location of Copenhagen Airport was prescribed in the Copenhagen Airport Expansion Act adopted by the Danish Parliament in 1980. This act was subsequently amended in 1992 [65]. The Act incorporates a balancing of the benefits to society of the environmental considerations on the one hand and the status of the airport's key role as an international traffic hub on the other. The Act has been implemented by a regional plan directive as well as a number of other local plans, which have provided a more detailed framework for the expansion of the airport.

The environmental impact of Copenhagen Airport is regulated by several authorities through a number of environmental approvals that have been provided under the Danish Environmental Protection Act. The Danish Environmental Protection Agency (DEPA), which is part of the Ministry of Environment and Food, is the agency responsible for national environmental legislation. The second authority is the local Municipality of Tårnby. The Municipality is responsible for local planning issues, including granting land use permits, and for taking into consideration other related environmental impacts, that are subject to environmental regulation. The Municipality is also the primary contact point for the public on all matters relating to the environment [66], with the exception of noise from air traffic and air quality.

Thus, Copenhagen Airports A/S (CPH) is subject to extensive environment-related regulation [67], and the starting point for the company's work is always full compliance with all its statutory and regulatory environmental, climate, and energy requirements. Copenhagen Airports A/S (CPH) environment and climate policy have been developed and implemented to ensure that both Copenhagen Airport and Roskilde Airport are operated and developed in a responsible manner. The company's policy also aims to ensure they can achieve sustained improvements in its environmental results. The company's responsibility includes the activities that are under its direct and indirect control and it endeavours to the widest possible degree to also influence the activities that are beyond its direct and indirect control. These include the activities under the control of the airport's business partners and customers.

The company is also a signatory to the UN Global Compact, and, as such, the environmental principles of the Global Compact are incorporated in its environmental and climate policy. Copenhagen Airport has also been accredited by the Airport Council International (ACI) Airport Carbon Accreditation program, which is the ACI's program for handling airport carbon footprints [67]. Copenhagen Airports A/S (CPH) reports its environmental impact in accordance with the principles of internationally accepted reporting standards, such as the Global Reporting Initiative as well as the Carbon Disclosure Project.

In addition, Copenhagen Airports $A / S(C P H)$ is a full member of the Nordic Initiative for Sustainable Aviation (NISA). The airport has an Environmental Management System (EMS) in place that is aligned with world best practice [68]. 


\subsection{Water Consumption at Copenhagen Airport}

Water is required at airports to service both the people using and working at the airport as well as to service airport facilities (for example, toilets) and equipment infrastructure. The volume of water supply is directly proportional to the volume of passengers that are using the airport facilities and their location [69]. The largest source of water consumption at Copenhagen Airport is from the 70,000 or so people that pass through or use the passenger terminals each day. Also, airlines, flight catering firms, and other airport tenants are responsible for their own water consumption, but they do obtain water from the airport's water supply system [70]. Figure 4 shows the annual total water consumption, as measured by cubic metres $\left(\mathrm{m}^{3}\right)$, at Copenhagen Airport from 2006 to 2016. The total annual water consumption has increased, illustrated by the positive trend in the year-on-year change, averaging $(5 \pm 3)$ percent. The peaks, or more specifically the lows, correspond to downturns in the aviation industry. This is because the aviation industry is highly sensitive to changes in global economic activity and major exogenous events.

The drinking water at Copenhagen Airport is sourced from the Taarnby and Dragør municipal water works. This water comes from their drinking water reservoirs which are in the immediate vicinity of the Copenhagen airport area. The annual consumption of drinking water, as measured by cubic metres $\left(\mathrm{m}^{3}\right)$, at Copenhagen Airport from 2006 to 2016 is presented in Figure 5. Similar trends are present to Figure 4, but the average annual change is actually slightly higher, skewed by the large increase from 2010 to 2011.

To help mitigate the drinking water consumption, Copenhagen Airport, wherever possible, uses non-potable water. The non-potable or second-quality water is sourced from a local aquifer and is used for toilet flushing in certain selected areas of the airport's terminals, for car washing and for cooling [70]. Figure 4 shows the annual total second quality water consumption, as measured by cubic metres $\left(\mathrm{m}^{3}\right)$, at Copenhagen Airport from 2006 to 2016 [51,71,72]. The quantities of non-potable water have been quite consistent, albeit with a high degree of variability.

Two important metrics that can be used to assess an airport's water consumption efficiency is the amount of water consumed per passenger and the amount of water consumed per aircraft movement. Figure 6 presents the annual water consumption per 1000 passengers and water consumed per aircraft movement, at Copenhagen Airport from 2006 to 2016. The "left" figure shows the water quantities (in litres) per passenger, for total, drinking, and second quality water. The "right" figure shows the water quantities (in $\mathrm{m}^{3}$ ) per aircraft movement, for total, drinking, and second quality water. If we compare these results to other factors such as energy $[65,73]$ or waste per passenger [74], there is a slightly increasing trend rather than a downward trend that we would expect in the results per aircraft movement (ATM). That is, while the airport has become more efficient in terms of energy and waste per aircraft, it is using more water per aircraft. This is explained by the changing nature of the aircraft operating at the airport, which have on average grown; the Airbus A380-800 aircraft began operating to Copenhagen Airport in 2015. However, looking at the water consumption per passenger, we note that the values are stagnant, having remained quite consistent over the period of the study. Again, when compared to energy and waste metrics (which have reduced over the same period), there appears to be no improvement in sustainability. To explain this, we need to consider that there is direct and indirect water consumption. So, the total water per passenger may have slightly increased; but this is due to an increase in water consumption that may not totally associated with passenger activities at the airport. It is important to note that the airport has grown and expanded over the period of study, with a new hotel opening in 2001, with steadily increasing patronage, in 2007 the metro station opened with associated facilities requiring water, in 2008 a new control tower opened, in 2010 a new low cost terminal opened, and in 2015, a new Boeing maintenance facility opened. It should be noted, that while these are separate organizational entities, and each independent business will be aware of their own water consumption, on the airport, the water is handled centrally through the airport. 


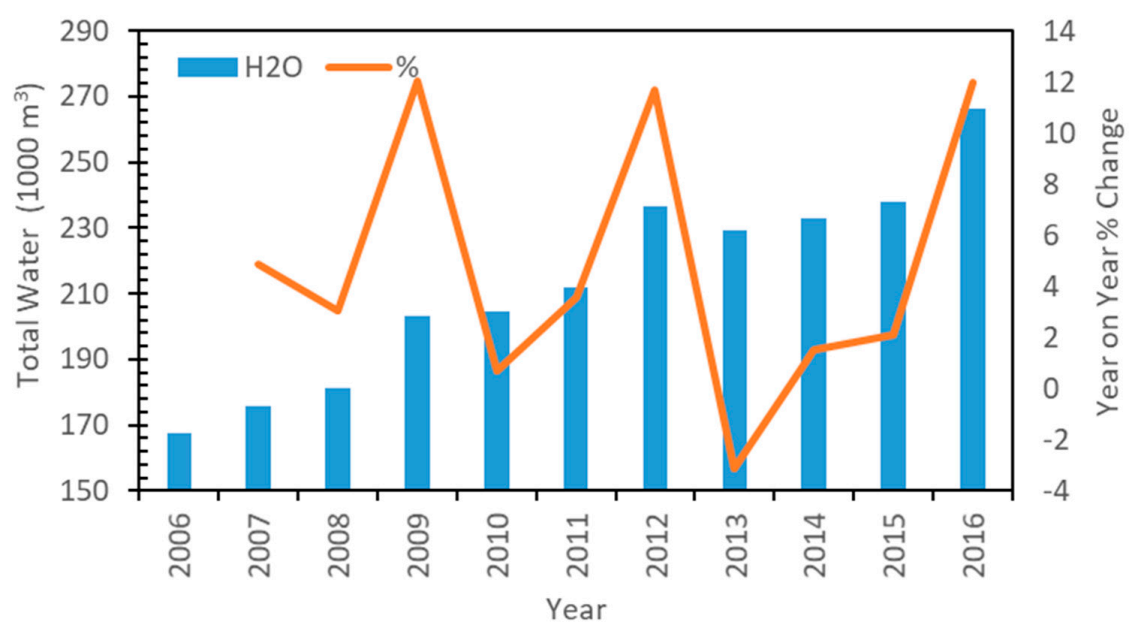

Figure 4. Total Water Consumption (Cubic Metres, $\mathrm{m}^{3}$ ) and Year-on-Year Change (\%) at Copenhagen Airport: 2006-2016. Source: data derived from [51,71,72].

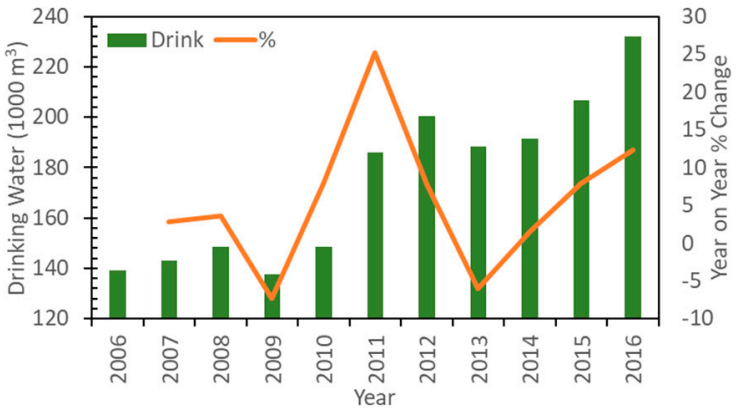

(a)

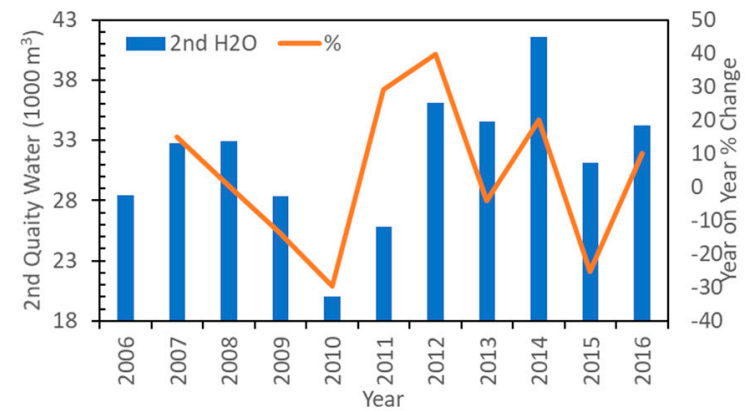

(b)

Figure 5. (a): Total Annual Drinking Water Consumption (Cubic Metres $\mathrm{m}^{3}$ ) and Year-on-Year Change $(\%)$ and (b): Total Annual Second Quality Water Consumption (Cubic Metres $\mathrm{m}^{3}$ ) and Year-on-Year Change (\%). Source: data derived from [51,71,72].

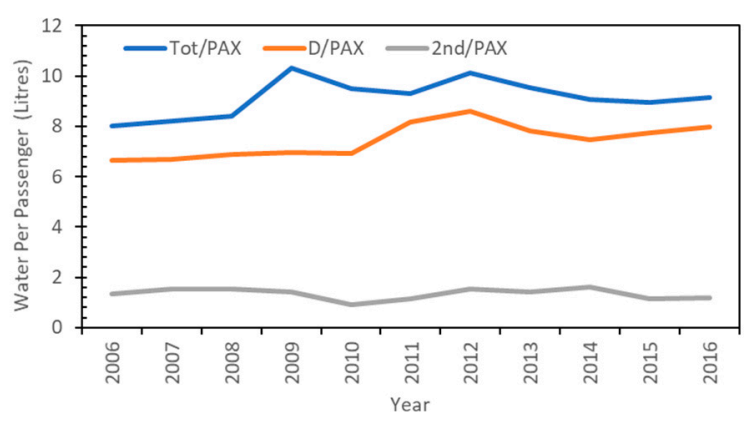

(a)

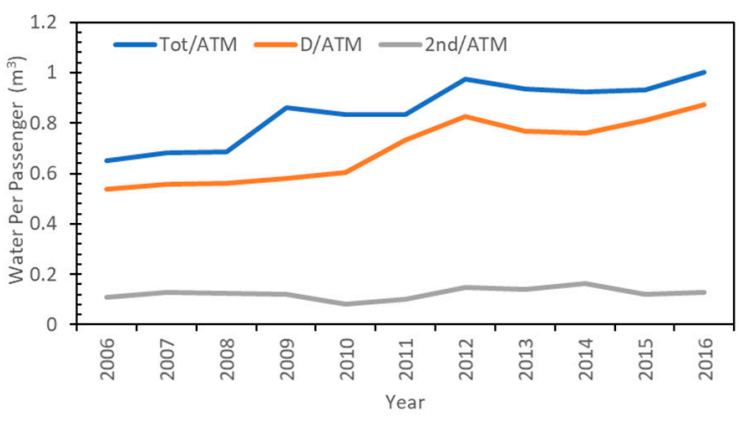

(b)

Figure 6. (a): Water Consumption Per Passenger and (b): Water Consumption Per Aircraft Movement, for total, drinking, and second quality water. Source: data derived from [51,71,72].

\subsection{Water Source Management at Copenhagen Airport}

\subsubsection{Drinking Water Quality Monitoring at Copenhagen Airport}

To ensure that there are no environmental risks and impacts on soil, water, and local communities from the operations at Copenhagen Airport the quality of drinking water, surface water, ground water, and soil conditions is monitored continuously in accordance with the relevant legislation. 
Furthermore, the airport is regulated by over 100 environmental approvals and permits, and the airport's self-regulation activities are reported annually to the environmental authorities [75]. Drinking water quality at Copenhagen Airport is monitored through the regular testing of the airport's supply of drinking water; water samples are sent to an external laboratory for analysis. There are 165 water samples taken each year at Copenhagen Airport [76].

\subsubsection{Ground Water Management at Copenhagen Airport}

The monitoring of groundwater quality is viewed as very important in Copenhagen Airport's activities and operations and the environmental impact that such waters may have on soil and groundwater [73]. Groundwater in the soil under the airport is in a layer of limestone which is approximately ten metres below the surface. Groundwater is formed form rainwater that seeps through the soil and subsequently fills up the pores of the limestone [76].

The groundwater at Copenhagen Airport is monitored by a monitoring program that has been designed in collaboration with the Taarnby municipal authorities. The ground water monitoring program provides an aggregate overview of the airport's groundwater conditions. The monitoring of ground water quality is an important part of the airport's environmental focus as the airport areas form part of the drinking water resources for the Copenhagen metropolitan area [76].

There are around 50 monitoring wells included in the airport's ground water monitoring program. The program includes the collection of water samples and determination of the groundwater level, that is, the program monitors how far the groundwater reservoir is beneath the ground surface [76].

Each year, 49 groundwater samples and 51 soundings of the groundwater level are taken at the airport. The gathered water samples are submitted for analysis to monitor the airport's groundwater quality. The information gathered as to how deep the groundwater surface is helps with the monitoring of movements in the groundwater reservoir [77].

According to Copenhagen Airports A/S [52], "in order to safeguard against substances potentially leaking from or ground water leaking into the airport's waste water and surface water pipes, oil separators, and wells, Copenhagen Airport prepared an action plan for the renovation of its surface water and waste water systems". The drainage renovation plan ran from 2003 until 2013. The renovation project commenced in 2003 in the airport's west and south area. In 2007, renovation of the surface and wastewater pipes located in the north-west area was completed [52]. In 2007, ten thousand metres of drainage pipes located at the eastern end of the airport's North Area were video inspected. This preliminary inspection provided the basis for the renovation of 2300 metres of drainpipes that was subsequently undertaken in the area during 2008 [75].

Furthermore, when any soil or construction work is being undertaken at the airport, Copenhagen Airports A/S has a policy whereby the relevant environmental authorities are involved, and the groundwater resources are taken into consideration in such projects [51].

\subsection{Surface Water Management}

\subsubsection{Surface Water Quality}

The quality of surface water at Copenhagen Airport is primarily affected by any fuel spills and by the de-icing agents used when de-icing aircraft and runways/taxiways during the winter period. Thus, to minimize the discharge of oil components through the surface water system, around 143 oil separators have been installed in the airport area [68]. A fixed procedure of monthly sounding and emptying these oil separators whenever required ensures the optimal removal of oil. This practice ensures that they do not enter the surface water system. In the fire drill area, which is in the south area of the airport, surface water and the water that is used when fire drills are conducted is collected. This water is subsequently discharged via a system of oil separators and coal filter plants prior to it entering the surface water system. Thus, at Copenhagen Airport, the surface water is discharged into the Øresund after it has passed through oil separators that remove any oil that may be present 
in the water. Also, to satisfy regulatory requirements, the airport must monitor surface water quality to ensure that regulatory water quality requirements are satisfied prior to the water being discharged into the Øresund [78].

\subsubsection{Discharge of Surface Water into the Øresund}

Copenhagen Airport has installed an extensive drainage system to ensure that the airport area is not flooded by heavy rains. The runway area is in a low-lying area, and thus, it is necessary for the airport to have large rainwater pools to collect rain water from heavy rain showers [76]. This separate drainage system for surface water has substantially reduced the volume of water that needs to be treated at the external water processing plants.

The largest contribution of surface water at the airport comes from the terminal area, where most of the areas are paved. Approximately 30 percent of the airport's total area of 11.8 square kilometres is paved, that is, it is used for car parks, aircraft runways and taxiways, roads, and buildings [77].

To ensure that these paved areas are also kept free of rainwater, Copenhagen Airport has a drainage system which ensures that rainwater is kept out of wastewater system. This division of the sewer system into two separate systems ensures that the local wastewater treatment plants are not required to handle very significant volumes of rainwater in addition to wastewater discharges. A total of 116 surface water samples are taken annually to monitor the water quality prior to its discharge into the Øresund [79].

Figure 7a shows the annual volume of surface (rain) water and the year-on-year change (\%) that was discharged from Copenhagen Airport into the Øresund from 2009 to 2016. The volume of discharge water has remained constant over the period of the study with an average value of $(2.4 \pm 0.2)$ $\times 10^{6} \mathrm{~m}^{3}$.

\subsection{Wastewater Management}

\subsubsection{Wastewater System}

Copenhagen Airport has two separate sewer systems in place for handling wastewater and rainwater, respectively. Importantly, the two types of water are not discharged to the same system as the composition of the two types of water is quite different in nature [79].

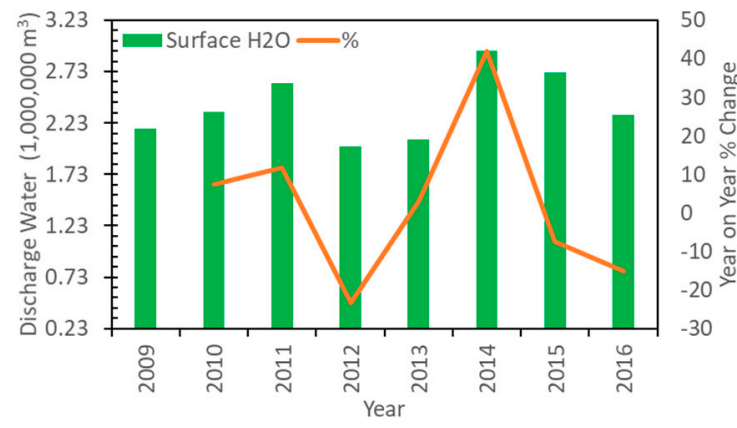

(a)

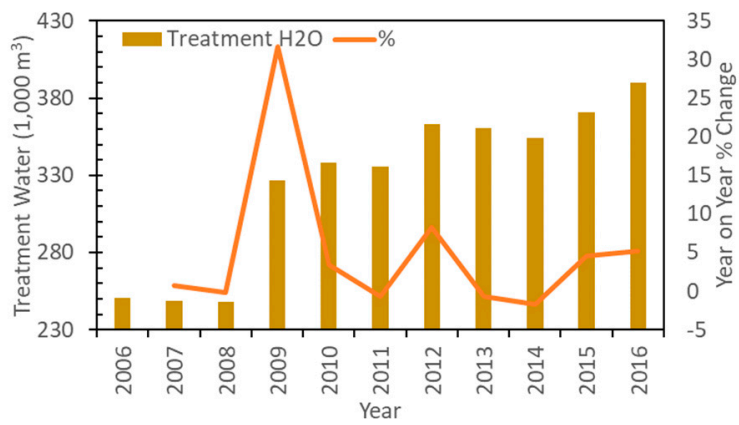

(b)

Figure 7. (a): surface Water Discharged (Cubic Metres $\mathrm{m}^{3}$ ) into the Øresund from Copenhagen Airport 2009-2016 and Year-on-Year Change (\%). (b): Total Waste Water (Cubic Metres $\mathrm{m}^{3}$ ) Discharged into the Øresund and Year-on-Year Change (\%) by Copenhagen Airport: 2006-2016. Notes: Copenhagen Airports A/S commenced publishing the data on the total waste water discharged into the Øresund in 2011 with the initial three years of historical data (2009-2011). Source: data derived from [51,71,72]. 


\subsubsection{Discharge of Waters to Water Treatment Plants}

Copenhagen Airport also discharges wastewater to treatment plants located in the municipalities of Taarnby and Dragør. The wastewater that is generated in the north, east and west areas of Copenhagen Airport is discharged to the Taarnby water treatment plant. The wastewater from the southern area of the airport is discharged to the Dragør water treatment plant [78]. The largest volume of wastewater from the airport is discharged to the Taarnby processing plant. There are many different activities that influence the composition of the wastewater at the airport. However, this is mostly because of the following activities:

- The terminal area (the estimated 70,000 passengers per day)

- Staff canteens and locker rooms

- Maintenance activities such as hangars, vehicle repair facility and the washing facility for vehicles

- Production of in-flight meals

- Disposal of wastewater from aircraft [79].

The composition of the wastewater generated from the terminal activities in the north area of the airport corresponds to ordinary domestic water. One of the principal sources of wastewater in the east area is the discharge from a flight catering centre. The wastewater generated in the west and south areas of the airport comes from a staff canteen, maintenance facilities for aircraft, and other equipment [75].

The production of meals served on aircraft, at restaurants, and in the staff-canteen contributes both grease and detergents in the airport's wastewater. Due to the flat topography along the coastal road bordering the airport, Copenhagen Airport has installed a pressure pipe system which has replaced the conventional water pipes. However, hydrogen sulphide $\left(\mathrm{H}_{2} \mathrm{~S}\right)$ has been found. This is formed when organic material such as grease degrades. The formation of hydrogen sulphide $\left(\mathrm{H}_{2} \mathrm{~S}\right)$ has been controlled at the airport using calcium nitrate $\mathrm{Ca}\left(\mathrm{NO}_{3}\right)_{2}$. However, the use of calcium nitrate can result in higher nitrogen levels in the wastewater [31] (p. 15).

One of the principal maintenance-related activities contributing to wastewater at the airport is the washing of aircraft. To protect Copenhagen Airport surface water system as well as the Øresund from pollution with heavy metals, the airlines established plants for collection of aircraft wash water in mid-2002. Part of this wash water is purified in the airport area itself, and part of it is transported to an external recipient for processing [80].

Figure $7 \mathrm{~b}$ presents the total volume of wastewater discharged for treatment at the Taarnby and Dragør treatment plants for the period 2006 to 2016. The annual volume of water sent for treatment has increased, which is not a negative aspect, as it means more water is treated if necessary and less pollutants are introduced into the environment.

\subsection{Water Contaminants}

As noted earlier, the organic water pollution indicators that are commonly used by airports to measure water pollution are chemical oxygen demand (COD), total nitrogen (T-N), and total phosphorous (T-P) [24]. Copenhagen Airport takes flow-proportional 24-h samples monthly. These samples are analysed by external laboratories to determine the levels of the following parameters: phosphate, nitrogen, detergents, and chemical oxygen demand (COD) [31].

Figure 8 a shows the annual discharges of detergents and oils and grease from Copenhagen Airport from 2006 to 2015. A noticeable decrease to 2009 is apparent, and statistically significant (1-tailed 2 -sample $t$-test assuming equal variance, 2006-2008 v 2009-2015, $p$-value $\left.=4.7 \times 10^{-5}\right)$. Hence the initiatives implemented to reduce the detergents have clearly been effective. In contrast, the oil and grease rate have remained fairly consistent, with an average quantity of $(3 \pm 0.7)$ tonnes per annum.

The total annual discharge of nitrates $(\mathrm{N})$ and phosphates $(\mathrm{P})$ at Copenhagen Airport from 2006 to 2015 are shown in Figure 8b. Both the nitrates and phosphates have remained constant over the period of the study, averaging $(25 \pm 1)$ tonnes and $(2 \pm 0.2)$ tonnes, respectively. 
The chemical oxygen demand (COD) at Copenhagen Airport from 2006 to 2015 is presented in Figure 8c. There is the potential for an underlying trend that is reducing, but the high degree of scatter means the COD should be described as constant, with an average of $(134 \pm 13)$ tonnes.

Figure $8 \mathrm{~d}$ shows the annual discharge of heavy metals lead and cadmium, while Figure $8 \mathrm{e}$ shows the annual discharge of heavy metals chrome and nickel - at Copenhagen Airport from 2006 to 2015. The "steady state" trend in the most recent years for each of the heavy metals suggests that there has been a concerted effort to reduce the heavy metal contaminants at Copenhagen Airport. Testing these yields the following for 1-tailed, 2-sample t-test assuming equal variance:

- $\quad$ Lead: $2006-2010$ v 2011-2015, $p$-value $=0.001$

- Cadmium: 2006-2009 v 2010-2015, $p$-value $=0.02$

- Chromium: 2006-2010 v 2011-2015, $p$-value $=0.003$

- Nickel: 2006-2009 v 2010-2015, $p$-value $=0.006$

Each of these is statistically significant, indicating that the quantities of heavy metal contaminates has reduced over the study period.

The annual discharge of copper and zinc from Copenhagen Airport for the period 2006 to 2015 are presented in Figure 8f. These two metals have less environmental impact than the previous four heavy metals [81]. Repeating the analysis above yield the following for 1-tailed, 2-sample $t$-test assuming equal variance:

- Copper: 2006-2010 v 2011-2015, $p$-value $=0.0001$

- Zinc: $2006-2010$ v 2011-2015, $p$-value $=0.005$

Both of these are statistically significant, indicating that the quantities of these metal contaminates has reduced.

\subsection{Use of Ground Water for Cooling at Copenhagen Airport}

Air conditioning systems at airports ensure the comfort of passengers and airport staff; however, these systems can consume substantial amounts of water [2]. An approach receiving much attention is the use of thermal energy storage (TES) for space heating and cooling [82]. Aquifer thermal energy storage (ATES) has not only the associated energy improvement associated in general with ATES, it also does not require the use of municipal water as a heating and cooling fluid; hence, ATES offers water saving benefits as well.

Copenhagen Airport began installing an ATES system in 2010, for use in the "CPH Go Terminal", specifically both Piers D and C, as well as the baggage area. The system is intended to provide cooling in summer, with heating in winter a secondary function. The system will be comprised of five aquifer dipoles, where a dipole is a pair of wells, one hot and one cold, relatively speaking. The water is drawn from the saline groundwater, preventing any impact on the fresh groundwater at Copenhagen Airport. This then requires the wells to be around $110 \mathrm{~m}$ below the surface. The limestone layer through which the water flows is ideal for storing and recovering heat. The principle of the ATES system is illustrated in Figure 9. This shows both the heating and cooling scenario. For heating, warm water is pumped up from the warm water side of the dipole so that heat can be extracted, the cooler water is then discharged into the cold side of the dipole. For cooling the process is reversed, such that cold water is initially pumped up where heat is absorbed, and the warm water is then discharged into the warm side of the dipole [83].

In 2013, the airport's ATES groundwater cooling system was expanded further in synergy with the large-scale improvements being undertaken in Terminal 2. Eight out of ten cooling wells were in operation [51].

The penultimate stage of the ATES systems was completed in 2014 at which time the entire Pier B and $C$ and parts of Terminal 2 were being cooled by the system. The completion of this phase of the ATES project resulted in a thirty per cent increase in the system's cooling capacity [82]. 


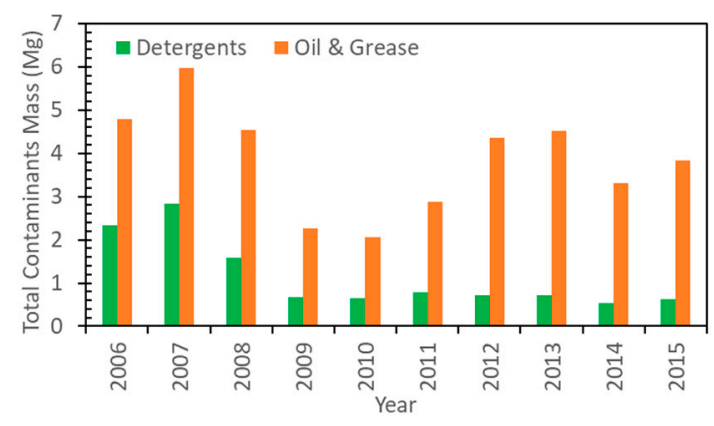

(a)

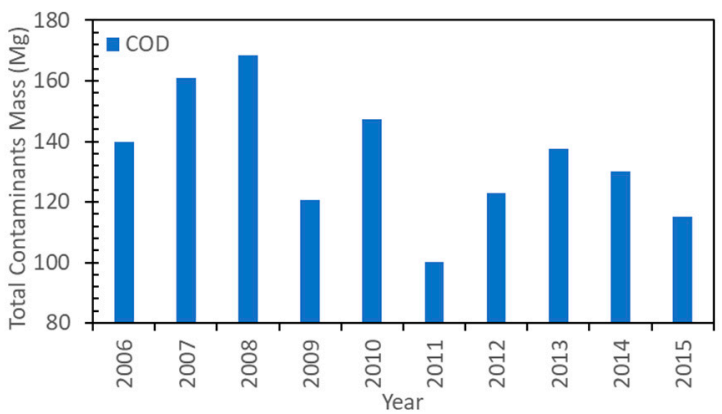

(c)

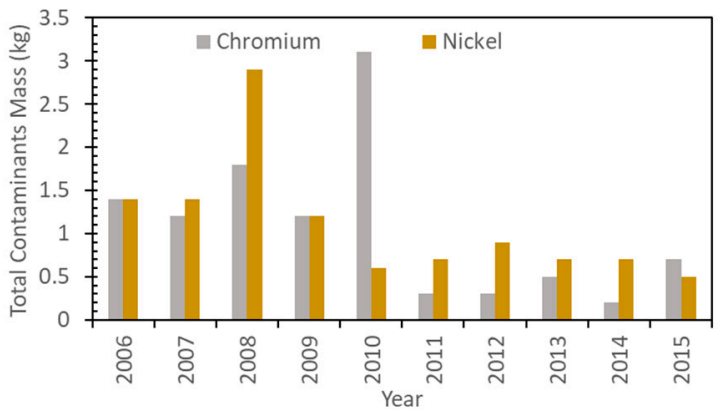

(e)

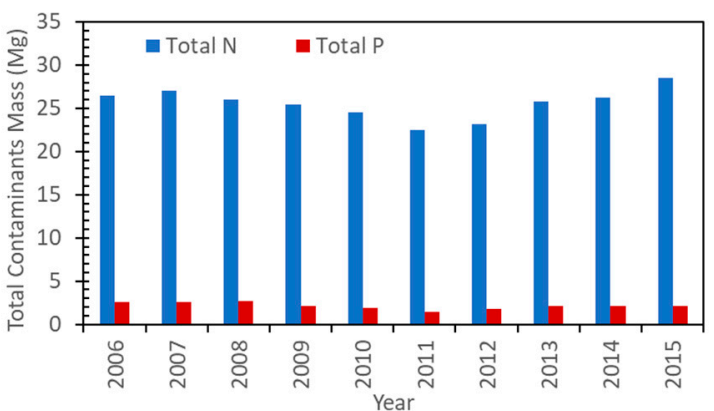

(b)

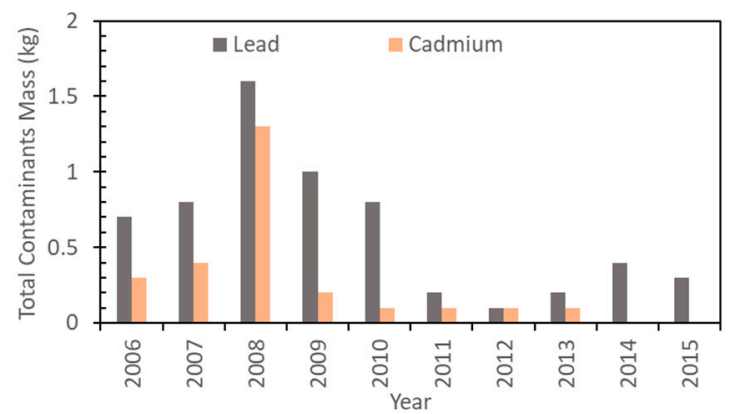

(d)

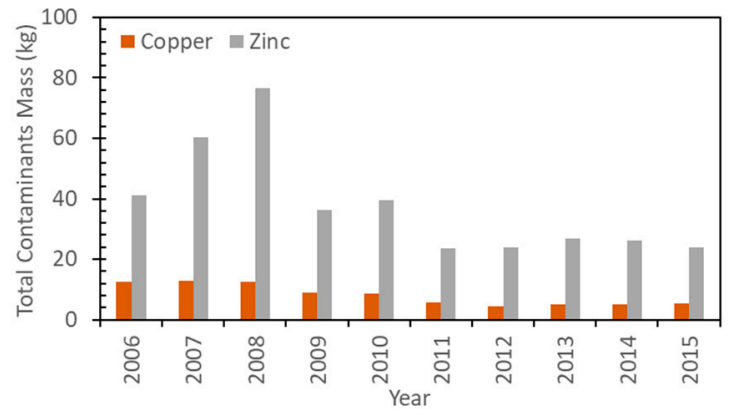

(f)

Figure 8. (a): Total Annual Discharge of Detergents and Oil and Grease Products (Kilograms) at Copenhagen Airport: 2006-2015. (b): Total Annual Discharge of Nitrates (N) and Phosphates (P) (Kilograms) at Copenhagen Airport: 2006-2015. (c): Total Annual Discharge of Chemical Oxygen Demand (COD) (Kilograms) at Copenhagen Airport: 2006-2015. (d): Total Annual Discharge of Lead and Cadmium (Kilograms) at Copenhagen Airport: 2006-2015. (e): Total Annual Discharge of Chromium and Nickel (Kilograms) at Copenhagen Airport: 2006-2015. (f): Total Annual Discharge of Nickel and Zinc (Kilograms) at Copenhagen Airport: 2006-2015. Note: 2016 data not published. Source: data derived from $[50,52,72,75]$.

By 2015, eight wells had been established (four dipoles) and these were being used by the airport to supply heating and cooling to the CPH Go terminal, Pier D, and the baggage area, along with the airport's newly renovated and expanded Pier C. Each of the wells are around $110 \mathrm{~m}$ deep to reach the saline groundwater aquifer. At a depth of $110 \mathrm{~m}$, the groundwater flow through the porous limestone layer is optimal for storing and recovering heat. In addition, circulation at that depth especially also prevents any impact on fresh groundwater. The saline groundwater circulates in a closed loop underground, thereby acting as a closed-system heat exchanger providing heat and cooling in a closed-loop system to the previously mentioned terminal buildings. During summer 
periods, when the terminal buildings require cooling, the dipoles circulate the water, carrying cold water from the cold well into the terminal buildings. Once in the terminals, the cold-water acts as a heat exchanger as absorbs the heat of the warmer terminal air and subsequently lowers the terminal buildings temperature. Once the water has become warm, it is then injected into the warm well. As the warm water flows towards the cold well, it is then cooled by the lower ambient temperature in the aquifer. During the winter period, when the terminal buildings require heating, the system is reversed. This circulation and heat exchange therefore make it possible for the airport to store and recover a large amount of heat in the underground limestone layer. Copenhagen Airport's ATES system is anticipated to cost around DKK 60 million. The system will provide an estimated DKK 7 million in annual energy savings for the airport [83] (p. 2).

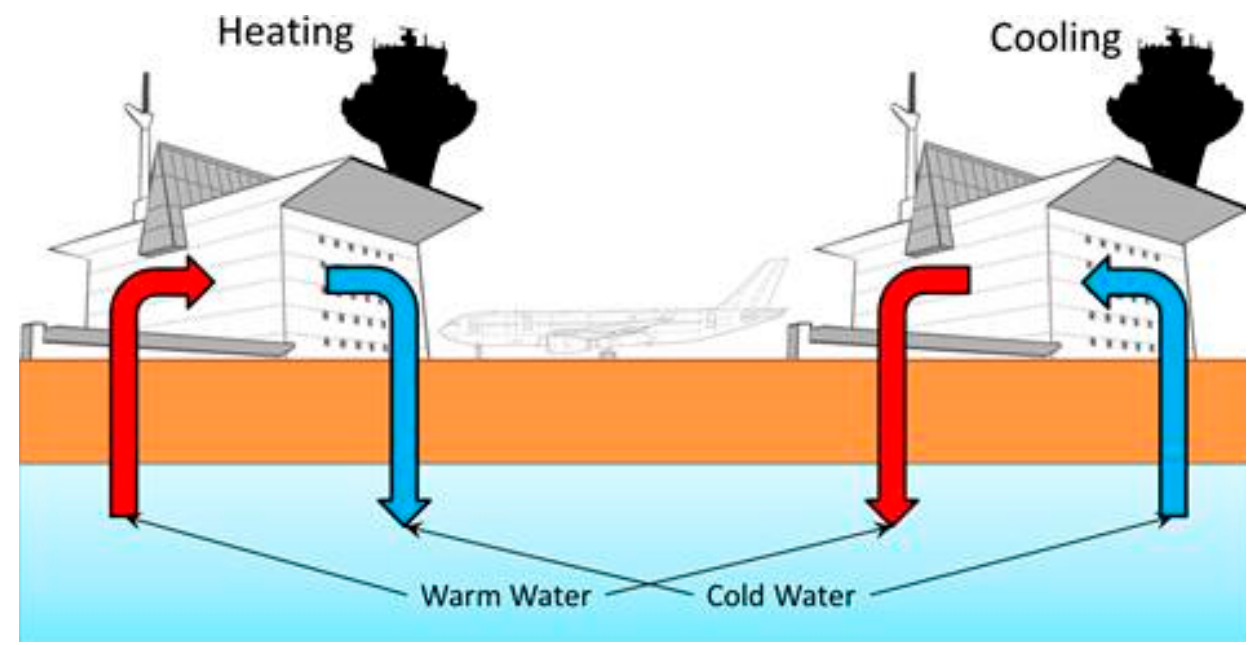

Figure 9. Aquifer Thermal Energy Storage (ATES) System showing heating of an Airport in Winter by Pumping Water in from the Warmer half of the Dipole (Left) and Cooling in Summer by Pumping Water in from the Cooler Half of the Dipole (Right). Source: adapted from [83].

During 2015, the airport completed the final phase of the production side of the groundwater cooling system (ATES). Upon completion of the production phase in 2015, the ATES system could supply approximately 4 million kWh of cooling annually. This was twenty per cent higher than 2014 levels [84].

In 2016, the first stage of a major heat pump project associated with the groundwater cooling system (ATES) was completed at the airport. Consequently, the cold water used for cooling in the summer is now able to be used to generate district heating for the remainder of the year by leading it through a heat pump. It is envisaged that the second and final stage will be executed at the start of 2017 [68].

\subsection{Further Water Saving Initiatives at Copenhagen Airport}

During 2014, Copenhagen Airports A/S completed a thorough renovation of the airport's fire training area. This renovation incorporated several environmental measures, which especially focused on water consumption, water treatment, and the use of gas rather than jet fuel that is used in fire training drills. The other key environmental aspects of the new fire-training mock-up is a larger collection area as well as the option to use second quality water both for cooling off the mock-up and for filling the fire trucks [51].

During the summer of 2015, Copenhagen Airport as part of its plan to accommodate the predicted traffic growth, undertook a project that renovated and widened runway $22 \mathrm{~L} / 04 \mathrm{R}$. This project included the installation of a new surface water management system that will help to ensure that there is adequate drainage on and around the runway in the years to come [84].

In 2016, Copenhagen Airports A/S increased their focus on the use of second quality water, which as previously noted, is used for vehicle washing, for toilet flushing in Terminal 2 and for 
cooling in selected stores. During 2016, the airport operator mapped the entire second-quality water system to identify further potential applications. This mapping project resulted in the optimization of the ventilation of one of Copenhagen Airport's primary server rooms. This server room is now exclusively cooled using second-quality water. In addition to being an environmentally-friendly solution, this initiative has also reduced the high costs incurred with conventional cooling. It has also delivered energy savings of $145,000 \mathrm{kWh}$ per annum to the airport [72].

\section{Discussion}

\subsection{Findings}

First and foremost, it should be noted that over the period of the study, $\mathrm{CPH}$ has grown and expanded, with passenger numbers increasing by almost 50\% from 2006 to 2016, which is an annual growth rate of just over 3\%. The latest terminal building opened in late 2010, and in 2008 a new tower was opened, while in 2015 Boeing Commercial Airplanes opened a maintenance facility. All these developments required water usage in the construction phase and would result in an increased demand. Despite this, the water consumption per passenger at the airport has remained constant. In fact, when looking at the cross-sectional study of de Castro Carvalho et al [2], the water consumption at $\mathrm{CPH}$ is actually lower than any airport previously investigated.

The most interesting finding is in line with the first proposed research hypothesis, which is that the total water consumed has increased for $\mathrm{CPH}$. However, in contrast to the expected reduction in water consumption per unit of traffic (PAX or ATM), this has also remained steady (or increased in the case of ATM). Water management initiatives at other airports [85] have focused on the reduction of water consumption. However, the clear finding is that the initiatives at $\mathrm{CPH}$ are targeted at reducing the environmental impact of the airport in terms of the quality of the water discharged from the airport.

The primary source of water is through the municipal water supply. This, however, is subsidized as expected through the use of local ground water. The local ground water is used for the flushing of toilets, washing activities, and for cooling applications. This is very similar to the strategies for sourcing water used in other airports [86].

Interestingly, $\mathrm{CPH}$ has two wastewater system, one to handle rainwater, and the other for dedicated wastewater. These wastewaters are sent off site for treatment before being discharged. This is in contrast to other airports, which utilise their own wastewater treatment plants on site [85]. There will be pros and cons to each approach, but clearly nearby off site water treatment plants are a valid option, as demonstrated by $\mathrm{CPH}$.

In addition to the water quality metrics hypothesized to be monitored, $\mathrm{CPH}$ also monitors phosphates, detergents, and oils/greases. The number of heavy metals monitored covers the major pollutants and is similar in scope to those reported by other airports [87].

Interestingly, the standard reduce, reuse, and recycle strategies implemented in many other sustainability initiative are not overly apparent in the sustainable water management practices of $\mathrm{CPH}$. The core theme of sustainable water management at CPH appears to be "sustainable sourcing". That is, reducing the load on municipal water supplies by implementing second quality water, source directly, in as many applications as possible. At other airports, the primary sustainability initiative tends to be on either reduce or recycle [85]. Sustainable sourcing is an important strategy, that can be utilized in other airports, depending on the local ground water, in terms of availability and composition.

\subsection{Recommendations}

Airports traditionally divide their precinct into the landside and air side areas [6]. A limitation of the present study was that Copenhagen Airport's water data was at the aggregate airport level. Thus, it was not possible to investigate the specific differences between the airport's airside and landside areas. 
A further limitation of the study was that the metering system used to facilitate the water balance at Copenhagen Airport was not publicly available. The water balance involves the evaluation of water inputs, outputs, and storage variations of a given system, whether they are natural or artificial over a given time period [88].

\subsection{Future Work}

Future work on airport sustainable water management will look at a cross-sectional study to investigate how Copenhagen Airport compares to other airports globally. This will enable a detailed understanding of how different global regions are addressing sustainable water management. A future study could examine the measurement protocols and systems used by airports to measure contaminants generated at the airport.

Future research could examine the metering of airport's water balance in both the airside and landside precincts. In general, it would also be interested in to understand the composition of the wastewater, and the relative proportions based on the activities identified in Section 5.5.2.

\section{Conclusions}

The overall goal of this study was to examine, for the first time, sustainable airport water management. This goal was achieved via the research objectives; the primary objective being to empirically examine the sustainable water management strategies defined and implemented by Copenhagen Airport and to examine the methods, water quality monitoring, and the systems used by the airport to reduce the environmental impact of the water consumed and generated at the airport. This work is a direct continuation of previous work qualitatively analyzing the sustainability initiatives and environmental management at $\mathrm{CPH}$, specifically investigating waste management [88], and energy management [64].

The first research question was "What is the annual water consumption at Copenhagen Airport and has this changed over the period 2006 to 2016?" From 2006 to 2016, the annual water consumption at Copenhagen Airport increased from $167,678 \mathrm{~m}^{3}$ in 2006 to $266,255 \mathrm{~m}^{3}$ in 2016. During the review period from 2006 to 2016, Copenhagen Airport experienced strong passenger traffic growth. The annual number of aircraft movements varied over the study but have steadily increased from 2012 to 2016. The water consumption per passenger has shown a steady level, while the airport has grown and expanded over the decade of investigation. The consumption per aircraft has increased, however, this is due to the changing nature of that aircraft servicing the airport, specifically the increase in aircraft size.

The second research question was "What are the principal sources of water used at Copenhagen Airport?" The drinking water at Copenhagen Airport is sourced from the Taarnby and Dragør municipal water works. Copenhagen Airport has focused on mitigating the use of drinking water and uses non-potable water wherever possible. The non-potable or second-quality water is sourced from a local remedial drilling and is used for toilet flushing in certain selected areas of the airport's terminals, for car washing and for cooling.

The third research question was "How does Copenhagen Airport manage its surface and waste waters?" Copenhagen Airport has two separate sewer systems in place for handling wastewater and rainwater, respectively. Importantly, the two types of water are not discharged to the same system as the composition of the two types of water is quite different in nature. Copenhagen Airport has installed an extensive drainage system to ensure that the airport area is not flooded. The runway area is in a low-lying area, and thus, it is necessary for the airport to have large rain water pools to collect rain water from heavy rain showers. This separate drainage system for surface water has substantially reduced the volume of water that needs to be treated at the external water processing plants. Copenhagen Airport also discharges wastewater to treatment plants located in the municipalities of Taarnby and Dragør. The largest volume of wastewater from the airport is discharged to the Taarnby processing plant.

The fourth research question was "What measures are used to monitor water quality at Copenhagen Airport?" To ensure that there are no environmental risks and impacts on soil, water, and local 
communities from the operations at Copenhagen Airport the quality of drinking water, surface water, ground water, and soil conditions is monitored continuously. Drinking water quality at Copenhagen Airport is monitored through the regular testing of the airport's supply of drinking water; water samples are sent to an external laboratory for analysis. The monitoring of groundwater quality is viewed as very important in Copenhagen Airport's activities and operations and the environmental impact that such waters may have on soil and groundwater. The groundwater at Copenhagen Airport is monitored by a monitoring program that has been designed in collaboration with the Taarnby municipal authorities. At Copenhagen Airport the surface water is discharged into the Øresund after it has passed through a number of oil separators that remove any oil that may be present in the water.

The final research question was, "What initiatives have been implemented by Copenhagen Airport to mitigate water consumption during the period 2006 to 2016?" During the study period, there were several key water-related initiatives that were implemented by Copenhagen Airport in order to mitigate water consumption at the airport. These initiatives included an Aquifer Thermal Energy Storage (ATES) system which is used for cooling (and heating during winter), a new surface water management system to help ensure adequate drainage on runway $22 \mathrm{~L} / 04 \mathrm{R}$, the renovation of the airport's fire-fighting training area, and the use of second quality water for cooling the airport's server room.

In general, Copenhagen Airport ( $\mathrm{CPH}$ ) has proven an interesting case study for sustainable airport water management. The growth in passenger and airport operations while maintaining a steady level of water consumption illustrates the success of the water related initiatives. The success of these initiatives is further highlighted by the reduction in contaminants measured over the period of the study, again while airport utilization has increased. While many of the strategies are typical in the context of sustainable water management, the review of the initiatives here will hopefully help future airport developments ensure that adopt sustainable water management strategies and systems.

Author Contributions: G.B. conceived the paper, writing the first draft paper. All authors contributed equally to the data analysis and editing of the manuscript.

Funding: This research received no external funding.

Acknowledgments: The authors would like to express their sincere gratitude to Copenhagen Airports A/S for the permission to the use the airport's annual environmental performance data.

Conflicts of Interest: The authors declare no conflict of interest.

\section{References}

1. Somerville, A.; Baxter, G.S.; Richardson, S.; Wild, G. Sustainable water management at Australian regional airports: The case of Mildura Airport. Aviation 2015, 19, 83-89. [CrossRef]

2. de Castro Carvalho, I.; Calijuri, M.L.; Assemany, P.P.; e Silva, M.D.F.M.; Neto, R.M.F.; da Fonseca Santiago, A.; de Souza, M.H.B. Sustainable airport environments: A review of water conservation practices in airports. Resour. Conserv. Recycl. 2013, 74, 67-75.

3. do Couto, E.A.; Assemany, P.; Calijuri, M.C.; Alves, L. Reuse of treated sewage effluent in airports: Irrigation of ornamental plant nursery. J. Urban Environ. Eng. 2013, 7, 264-273. [CrossRef]

4. Neto, R.M.F.; Calijuri, M.L.; Carvalho, I.C.; da Fonseca Santiago, A. Rainwater treatment in airports using slow sand filtration followed by chlorination: Efficiency and costs. Resour. Conserv. Recycl. 2012, 65, 124-129. [CrossRef]

5. Vanker, S.; Enneveer, M.; Mäsak, M. Implementation of environmentally friendly measures at Tallinn Airport. Aviation 2013, 17, 14-21. [CrossRef]

6. Airport Technology. Copenhagen Airport, Denmark. Available online: https://www.airport-technology.com/ projects/copenhagenairport/ (accessed on 22 March 2019).

7. International Airport Review. The World's Top 20 Airports | 20 Years of International Airport Review. Available online: https://www.internationalairportreview.com/article/30877/worlds-top-20-airports/ (accessed on 22 March 2019).

8. Rossi Dal Pozzo, F. EU Legal Framework for Safeguarding Air Passenger Rights; Springer International Publishing: Cham, Switzerland, 2015. 
9. Thomas, C.; Hooper, P. Sustainable development and environmental capacity of airports. In Airport Operations, 3rd ed.; Ashford, N.J., Stanton, H.P.M., Moore, C.A., Coutu, P., Beasley, J.R., Eds.; McGraw-Hill: New York, NY, USA, 2013; pp. 553-578.

10. Chinn, R.W.; Vickers, K. Automated air cargo handling systems. Systems Engineering of Aerospace Projects. In Proceedings of the IEEE Colloquium on Systems Engineering of Aerospace Projects (Digest Number 1998/249), London, UK, 28-28 April 1998; pp. 1-9.

11. Graham, A. Managing Airports: An International Perspective, 4th ed.; Routledge: Abingdon, UK, 2014.

12. Halpern, N.; Graham, A. Airport Marketing; Routledge: Abingdon, UK, 2013.

13. do Couto, E.; Calijuri, M.L.; Assemany, P.P.; da Fonseca Santiago, A.; de Castro Carvalho, I. Greywater production in airports: Qualitative and quantitative assessment. Resour. Conserv. Recycl. 2013, 77, 44-51. [CrossRef]

14. Neto, R.M.F.; Carvalho, I.C.; Calijuri, M.L.; da Fonseca Santiago, A. Rainwater use in airports: A case study in Brazil. Resour. Conserv. Recycl. 2012, 68, 36-43. [CrossRef]

15. London Heathrow Airport. World Water Day and Heathrow. Available online: https://your.heathrow.com/ celebrating-world-water-day-heathrows-story/ (accessed on 21 March 2019).

16. Dimitriou, D.J.; Voskaki, A.J. Regional airports' environmental management: Key messages from the evaluation of ten European airports. In Regional Airports; Postorino, M.N., Ed.; WIT Press: Southampton, UK, 2011; pp. 73-86.

17. Rossi, G.; Cancelliere, A. Managing drought risk in water supply systems in Europe: A review. Int. J. Water Resour. Dev. 2013, 29, 272-289. [CrossRef]

18. Chen, Z.; Ngo, H.H.; Guo, W. A critical review on sustainability assessment of recycled water schemes. Sci. Total Environ. 2012, 426, 13-31. [CrossRef] [PubMed]

19. Yu, Z.L.T.; Rahardianto, A.; DeShazo, J.R.; Stenstrom, M.K.; Cohen, Y. Critical review regulatory incentives and impediments for onsite graywater reuse in the United States. Water Environ. Res. 2013, 85, 650-662. [CrossRef] [PubMed]

20. Gupta, A.D.; Onta, P.R. Sustainable groundwater resources development. Hydrol. Sci. J. 1997, 42, 565-582. [CrossRef]

21. Boyle, T.; Giurco, D.; Mukheibir, P.; Liu, A.; Moy, C.; White, S.; Stewart, R. Intelligent metering for urban water: A review. Water 2013, 5, 1052-1081. [CrossRef]

22. Bartram, J.; Balance, R. Water Quality Monitoring: A Practical Guide to the Design and Implementation of Freshwater Quality Studies and Monitoring Programmes; E\&FN Spon: London, UK, 1996.

23. Vurmaz, M.O.; Boyacioglu, H. Airport Water Consumption Footprinting. Environ. Ecol. Res. 2018, 6, 519-524. [CrossRef]

24. Sulej, A.M.; Polkowska, Ż.; Namieśnik, J. Analysis of airport runoff waters. Crit. Rev. Anal. Chem. 2011, 41, 190-213. [CrossRef]

25. Switzenbaum, M.S.; Veltman, S.; Mericas, D.; Wagoner, B.; Schoenberg, T. Best management practices for airport deicing stormwater. Chemosphere 2001, 43, 1051-1062. [CrossRef]

26. Leung, R.W.K.; Li, D.C.H.; Yu, W.K.; Chui, H.K.; Lee, T.O.; van Loosdrecht, M.C.M.; Chen, G.H. Integration of seawater and grey water reuse to maximize alternative water resource for coastal areas: The case of the hong kong international airport. Water Sci. Technol. 2012, 65, 410-417. [CrossRef]

27. Chu, S.C.K. Goal programming model for airport ground support equipment parking. In Multiple Objective and Goal Programming: Recent Developments; Trzaskalik, T., Michnik, J., Eds.; Physica-Verlag: Heidelberg, Germany, 2002; pp. 235-246.

28. Branchu, P.; Gres, L.; Mougin, F.; Le Blanc, M.; Lucas, E.; Mars, B. French airport runoff pollution management (water and sludge): Toward a new approach based on constructed wetlands? Case of Aéroports de Paris-Orly (France). Water Pract. Technol. 2014, 9, 20-32. [CrossRef]

29. Marais, K.; Wolfe, P.J.; Waitz, I.A. Air transport and the environment. In The Global Airline Industry, 2nd ed.; Belobaba, P., Odoni, A., Barnhart, C., Eds.; John Wiley \& Sons: Chichester, UK, 2015; pp. 423-459.

30. Culberson, S.D. Environmental impact of airports. In Airport Engineering: Planning, Design, and Development of 21st Century Airports, 4th ed.; Ashford, N.J., Mumayiz, S.A., Wright, P.H., Eds.; John Wiley \& Sons: Hoboken, NJ, USA, 2011; pp. 704-738.

31. Copenhagen Airports A/S. Environmental Report 2007; Copenhagen Airports A/S: Copenhagen, Denmark, 2008. 
32. Kazda, T.; Caves, B.; Kamenický, M. Environmental control. In Airport Design and Operation, 3rd ed.; Kazda, A., Caves, R.E., Eds.; Emerald Group Publishing: Bingley, UK, 2015; pp. 457-500.

33. Edwards, B. The Modern Airport Terminal: New Approaches to Airport Architecture, 2nd ed.; Spon Press: Abingdon, UK, 2005.

34. Young, S.B.; Wells, A.T. Airport Planning and Management, 6th ed.; McGraw-Hill: New York, NY, USA, 2011.

35. Horonjeff, R.; McKelvey, F.X.; Sproule, W.J.; Young, S.B. Planning and Design of Airports, 5th ed.; McGraw-Hill: New York, NY, USA, 2010.

36. McGormley, R.W. Guidebook of Practices for Improving Environmental Performance at Small Airports; ACRP Report 43; Transportation Research Board: Washington, DC, USA, 2011.

37. Fawell, J.K. Drinking water quality and health. In Pollution: Causes, Effects and Control, 5th ed.; Harrison, R.M., Ed.; RSC Publishing: Cambridge, UK, 2014; pp. 60-79.

38. Yan, J. Comprehensive Evaluation of Effective Biomass Resource Utilization and Optimal Environmental Policies; Springer: Heidelberg, Germany, 2015.

39. Grantham, D.J. Surface water contamination caused by airport operations. In Environmental Management at Airports: Liabilities and Social Responsibilities; Tunstall Pedoe, N., Raper, D.W., Holden, J.M.W., Eds.; Thomas Telford Publishing: London, UK, 1996; pp. 104-121.

40. Balsaraf, V.M.; Pawar, A.V.; Mane, P.A. Applied Chemistry, 2nd ed.; I.K. International Publishing House: New Delhi, India, 2010; Volume 1.

41. Copenhagen Airports A/S. About CPH: A Quick Overview; Copenhagen Airports A/S: Copenhagen, Denmark, 2017.

42. Star Alliance. Fly to 1,317 Destinations Worldwide with the Star Alliance Network. Available online: https:/flights.staralliance.com/en/ (accessed on 19 February 2019).

43. Copenhagen Airports A/S. Facts About CPH; Copenhagen Airports A/S: Copenhagen, Denmark, 2019.

44. Copenhagen Airports A/S. Catchment Area. Available online: https:/www.cph.dk/en/cph-business/aviation/ Catchment-Area/ (accessed on 15 June 2019).

45. Copenhagen Airports A/S. CPH: Strong Finish to Challenging Year, Press Release 24 February; Copenhagen Airports A/S: Copenhagen, Denmark, 2010.

46. Copenhagen Airports A/S. Passenger Record Driving Results, Press Release 26 February. Available online: https://www.cph.dk/en/about-cph/press/news/2015/2/fy2014_uk/ (accessed on 9 February 2019).

47. Copenhagen Airports A/S. Strong Growth at Copenhagen Airport, Press Release 01 March. Available online: https://www.cph.dk/en/about-cph/press/news/2017/3/strong-growth-at-copenhagen-airport/ (accessed on 9 February 2019).

48. Copenhagen Airports A/S. Group Annual Report 2012. Available online: https://cph-prod-cdn.azureedge. net/48cfc5/globalassets/8.-om-cph/6.-investor/arsrapporter/en/group-annual-report-2012.pdf (accessed on 22 March 2019).

49. Copenhagen Airports A/S. CPH and Society 2011. Available online: https://cph-prod-cdn.azureedge. net/48cd3d/globalassets/8.-om-cph/6.-investor/arsrapporter/en/cph-and-society-2011.pdf (accessed on 7 February 2019).

50. Copenhagen Airports A/S. CPH and Society 2012. Available online: https://cph-prod-cdn.azureedge. net/48cd3d/globalassets/8.-om-cph/6.-investor/arsrapporter/en/cph-and-society-2012.pdf (accessed on 7 February 2019).

51. Copenhagen Airports A/S. CPH and Society 2013. Available online: https://cph-prod-cdn.azureedge. net/48cd3d/globalassets/8.-om-cph/6.-investor/arsrapporter/en/cph-and-society-2013.pdf (accessed on 6 February 2019).

52. Copenhagen Airports A/S. Environmental Report 2008; Copenhagen Airports A/S: Copenhagen, Denmark, 2009.

53. Derrington, M.L. Qualitative Longitudinal Methods: Researching Implementation and Change; SAGE Publications: Thousand Oaks, CA, USA, 2019.

54. Saldaña, J. Longitudinal Qualitative Research: Analyzing Change through Time; Alta Mira Press: Walnut Creek, CA, USA, 2003.

55. Neale, B. What Is Qualitative Longitudinal Research? Bloomsbury Academic: London, UK, 2019.

56. Yin, R.K. Case Study Research: Design and Methods, 5th ed.; SAGE Publications: Thousand Oaks, CA, USA, 2014.

57. Oates, B.J. Researching Information Systems and Computing; SAGE Publications: London, UK, 2006.

58. Ramon Gil-Garcia, J. Enacting Electronic Government Success: An Integrative Study of Government-wide Websites, Organizational Capabilities, and Institutions; Springer Science+Business: New York, NY, USA, 2012. 
59. Fulcher, J.; Scott, J. Sociology, 4th ed.; Oxford University Press: Oxford, UK, 2011.

60. Scott, J.; Marshall, G. A Dictionary of Sociology, 3rd ed.; Oxford University Press: Oxford, UK, 2009.

61. Love, P. Document analysis. In Research in the College Context: Approaches and Methods; Stage, F.K., Manning, K., Eds.; Brunner-Routledge: New York, NY, USA, 2003; pp. 83-96.

62. Van Schoor, B. Fighting Corruption Collectively: How Successful are Sector-Specific Coordinated Governance Initiatives in Curbing Corruption; Springer VS: Wiesbaden, Germany, 2017.

63. O'Leary, Z. The Essential Guide to Doing Research; SAGE Publications: London, UK, 2004.

64. Baxter, G. A strategic analysis of Cargolux Airlines International position in the global air cargo supply chain using Porter's Five Forces Model. Infrastructures 2019, 4, 6. [CrossRef]

65. Baxter, G.; Srisaeng, P.; Wild, G. An assessment of airport sustainability, Part 2-Energy management at Copenhagen Airport. Resources 2018, 7, 32. [CrossRef]

66. European Investment Bank. Environmental and Social Data Sheet: CPH (Copenhagen) Airport Expansion TEN-T. Available online: http://www.eib.org/infocentre/register/all/69558856.pdf (accessed on 22 March 2019).

67. Copenhagen Airports A/S. Legal Framework. Available online: https://cph-prod-cdn.azureedge.net/4a4549/ globalassets/8.-om-cph/uk-faktaark-a-responsible-company-legal-framework.pdf (accessed on 22 May 2019).

68. Copenhagen Airports A/S. Environmental and Climate Policy. Available online: https://cph-prod-cdn.azureedge. net/4a4549/globalassets/8.-om-cph/uk-faktaark-a-responsible-company-environmental-and-climate-policy.pdf (accessed on 22 March 2019).

69. Shanks, N.E.L.; Bradley, A.L.V. Handbook of Checked Baggage Screening: Advanced Airport Security Operation; John Wiley \& Sons: Chichester, UK, 2004.

70. Copenhagen Airports A/S. About CPH: Water Consumption; Copenhagen Airports A/S: Copenhagen, Denmark, 2017.

71. Copenhagen Airports A/S. CPH and Society 2010. Available online: https://cph-prod-cdn.azureedge.net/48cd3d/ globalassets/8.-om-cph/6.-investor/arsrapporter/en/cph-and-society-2010.pdf (accessed on 25 July 2019).

72. Copenhagen Airports A/S. Group Annual Report: Facts \& Figures 2016. Available online: https://cph-prodcdn.azureedge.net/48cf3a/globalassets/8.-om-cph/6.-investor/arsrapporter/en/facts--figures-2016.pdf (accessed on 25 July 2019).

73. Baxter, G.; Sabatini, R.; Wild, G. Sustainable airport energy management: A case study of Copenhagen Airport. In Proceedings of the International Symposium on Sustainable Aviation, Istanbul, Turkey, 31 May-3 June 2015.

74. Baxter, G.; Srisaeng, P.; Wild, G. An assessment of airport sustainability, part 1-waste management at Copenhagen Airport. Resources 2018, 7, 21. [CrossRef]

75. Copenhagen Airports A/S. Environmental Report 2009; Copenhagen Airports A/S: Copenhagen, Denmark, 2010.

76. Copenhagen Airports A/S. Groundwater; Copenhagen Airports A/S: Copenhagen, Denmark, 2015.

77. Copenhagen Airports A/S. Waste and Surface Water; Copenhagen Airports A/S: Copenhagen, Denmark, 2017.

78. Copenhagen Airports A/S. Groundwater is Closely Monitored Closely; Copenhagen Airports A/S: Copenhagen, Denmark, 2017.

79. Copenhagen Airports A/S. About CPH: Waste and Surface Water; Copenhagen Airports A/S: Copenhagen, Denmark, 2017.

80. Copenhagen Airports A/S. Environmental Report 2002; Copenhagen Airports A/S: Copenhagen, Denmark, 2003.

81. Monteiro, S.C.; Lofts, S.; Boxall, A.B.A. Pre-assessment of Environmental Impact of Zinc and Copper Used in Animal Nutrition, Scientific/Technical Report Submitted to EFSA. Available online: https://efsa. onlinelibrary.wiley.com/doi/epdf/10.2903/sp.efsa.2010.EN-74 (accessed on 26 July 2019).

82. Pavlov, G.K.; Olesen, B.W. Thermal energy storage-A review of concepts and systems for heating and cooling applications in buildings: Part 1-Seasonal storage in the ground. HVACER Res. 2012, 18, 515-538.

83. Københavns Lufthavne A/S. ATES Ground Water Cooling (Aquifer Thermal Energy Storage); Københavns Lufthavne A/S: Copenhagen, Denmark, 2019.

84. Copenhagen Airports A/S. Group Annual Report: Facts \& Figures 2015. Available online: https://cph-prod-cdn. azureedge.net/48cf35/globalassets/8.-om-cph/6.-investor/arsrapporter/en/facts--figures-2015.pdf (accessed on 23 March 2019).

85. Baxter, G.; Srisaeng, P.; Wild, G. An assessment of sustainable airport water management: The case of Osaka's Kansai international airport. Infrastructures 2018, 3, 54. [CrossRef]

86. Gabrieli, R.; Divizia, M.; Donia, D.; Ruscio, V.; Bonadonna, L.; Diotallevi, C.; Villa, L.; Manzone, G.; Panà, A. Evaluation of the wastewater treatment plant of Rome airport. Water Sci. Technol. 1997, 35, 193-196. [CrossRef] 
87. Chilakos, P.; Kavouras, C. Water management at Athens international airport a critical approach. Bull. Geol. Soc. Greece 2004, 36, 2094-2101. [CrossRef]

88. Besbes, M.; Chahed, J.; Hamdane, A. National Water Security: Case Study of an Arid Country: Tunisia; Springer International Publishing: Cham, Switzerland, 2019.

(C) 2019 by the authors. Licensee MDPI, Basel, Switzerland. This article is an open access article distributed under the terms and conditions of the Creative Commons Attribution (CC BY) license (http://creativecommons.org/licenses/by/4.0/). 